\title{
Onderhoudstoekenning vir gades of vennote pendente lite en by egskeiding: Het ons 'n nuwe benadering?
}

\section{$1 \quad$ Inleiding}

Hierdie aantekening beoog om vas te stel of die beleid met betrekking tot onderhoudstoekenning vir vennote in 'n burgerlike vennootskap en gades in 'n huwelik by egskeiding verander het. Die aantekening gaan op twee gevalle konsentreer.

Die een geval wat ondersoek word, fokus op onderhoudstoekenning ingevolge Reël 43(1) van die Eenvormige Hofreëls en die ander omstandigheid bespreek onderhoudsvoorsiening ingevolge artikel 7(2) van die Wet op Egskeiding 70 van 1979.

Alvorens daar met die bespreking verder gegaan word, gaan die algemene beginsels vir onderhoudstoekenning kortliks bespreek word.

\section{Algemene beginsels vir onderhoudstoekenning}

Gades (en telkens wanneer na gades verwys word, sluit dit ook vennote ingevolge 'n burgerlike vennootskap in terme van die Civil Union Act 17 van 2006 in) is ex lege verplig om mekaar te onderhou. (Sien oa Oshry $v$ Feldman 20106 SA 19 (HHA) 24E-F).

Onderhoud kan geëis word indien die eiser 'n behoefte daaraan het en die verweerder dit gedeeltelik of ten volle kan voorsien. (Sien oa Botha $v$ Botha 20093 SA 89 (W) par 103; EH v SH 20124 SA 164 (HHA) parr 1314.)

Wanneer die huwelik (en telkens wanneer na huwelik verwys word, sluit dit ook 'n huwelik en 'n burgerlike vennootskap ingevolge die Civil Union Act 17 van 2006 in) beëindig word, kom die onderhoudsaanspraak gemeenregtelik tot 'n einde (sien oa Thomson $v$ Thomson 20103 SA 211 (W) 215G; Oshry parr 24-25; EH v SH 167H).

Beide artikel 7 van die Wet op Egskeiding 70 van 1979 en die Wet op Onderhoud van Langslewende Gades 27 van 1990 maak voorsiening dat onderhoud ook na beëindiging van die huwelik toegeken mag word.

Die onderhoudsaanspraak kom ook gemeenregtelik tot 'n einde wanneer 'n gade, die gesamentlike huishouding deur sy/haar onregmatige gedrag beëindig (vgl oa Stern v Stern 1928 (WLD) 148 150; Behr v Minister of Health 19611 SA 629 (SR) 630F-G 633F; Alarakha $v$ Alarakha 19753 SA 245 (RAA) 251E-F; Chamani v Chamani 19794 SA 804 (W) 806H-807A, 807B-C). Die onderhoudsaanspraak word volgens

How to cite: Van Schalkwyk 'Onderhoudstoekenning vir gades of venoote pendente lite en by egskeiding: Het ons http:/ldx.doi.org/10.17159/2225-7160/2015/205 
die beskouings van beide hoofregter Murray en regter Young in die geval van onregmatige beëindiging van die gesamentlike huishouding eerder opgeskort as beëindig en herleef, indien die "skuldige" gade nie na die gesamentlike huishouding kan terugkeer nie as gevolg van die onregmatige gedrag van die "onskuldige" gade (Behr $v$ Minister of Health 631D-E \& 634A-E onderskeidelik). Hahlo (The South African Law of Husband and Wife (1985) 137) voer as rede vir die opskorting van die onderhoudsaanspraak aan dat kos en skuiling in die gesinswoning te vinde is.

Met bovermelde algemene beginsels vir onderhoudsvoorsiening as agtergrond, skuif die fokus na Reël 43(1) van die Eenvormige Hofreëls.

\section{Reël 43(1) van die Eenvormige Hofreëls}

\section{Onderhoud pendente lite Ingevolge Reël 43(1) van die Eenvormige Hofreëls}

Reël 43(1) maak voorsiening dat 'n getroude persoon vir onder andere onderhoud pendente lite aansoek mag doen. (Getroude persoon sluit in 'n applikant wat beweer dat hy/sy 'n getroude persoon is, en hierdie bewering sonder stawende getuienis, deur respondent ontken word (sien oa Zaphiriou v Zaphiriou 19671 SA 342 (W) 345G; AM v RM 20102 SA 223 (OK) 227G-H). In Hoosein v Dangor (2010 2 All SA 55 (WKK) par 28), gaan die hof selfs verder en beslis dat "getroude persoon", 'n gade insluit wat ingevolge die Muslim geloof getroud is. Sien ook Carnelley 'Enforcement of the maintenance rights of a spouse, married in terms of Islamic law, in the South African courts' 2007 Obiter 340ev).

Om suksesvol met 'n aansoek vir onderhoud pendente lite te wees, word twee vereistes gestel naamlik een, dat die applikant 'n redelike kans op sukses in die hoofgeding het (sien oa Davis $v$ Davis 1939 (WLD) 108 110, 112; Von Broembsen v Von Broembsen 19481 SA 1194 (O) 1196; Hamman $v$ Hamman 1949 1 SA 1191 (W) 1193; Zaduck v Zaduck 19661 SA 78 (SR) 78H; Zaphiriou v Zaphiriou 346A; SH v EH 20115 SA 496 (OKP) parr [15] \& [20]; Nathan, Barnett \& Brink Eenvromige Hofreëls (1984) 2271; Hahlo supra 432) en twee, dat die applikant tydens die aansoek pendente lite geregtig is op onderhoud (sien oa Harrower $v$ Harrower 1909 TH 231 231; Davis v Davis supra 110-111, 112; Von Broembsen $v$ Von Broembsen 1196; Zaduck v Zaduck 79A-C; Zaphiriou $v$ Zaphiriou 346A; Taute v Taute 19742 SA 675 (OK) 676-677; AM v RM supra par 12; Hahlo supra 432). Dit bring mee dat aansoeke om onderhoud pendente lite gemeenregtelik afgewys is as die applikant nie geregtig is op onderhoud nie weens onder andere die rede dat applikant die gemeenskaplike huishouding onregmatig beëindig het (sien Chamani $v$ Chamani supra 806H-807A \& 807B-C). Die regsbeginsel wat hier toepassing vind, is die gemeenregtelike skuldbeginsel, wat sy ontstaan lank voor die nuwe egskeidingsbedeling in terme van die Wet op Egskeiding 70 van 1979, verkry het. Omdat die Wet op Egskeiding 70 van 1979 met 'n gemeenregtelike egskeidingsreg wat op skuld gebaseer 
is, weggedoen het, laat dit die vraag ontstaan in welke mate dit regshulp vir onderhoud pendente lite gaan beïnvloed. Sinclair ("Notes and comments' 1981 SALJ 89 97-98) huldig die volgende mening en stel die volgende oplossing voor:

... it is suggested that the criteria for relief pendente lite must match those applicable to ancillary relief upon divorce and not those of the common law which determine the right to maintenance stante matrimonio ... To justify to an errant wife the fact that she is not entitled to maintenance pending divorce because determination of the duty of support during marriage hinges upon marital good behaviour, when only weeks later or months later judgment in the main action and an award of maintenance can be granted in her favour, will not be an easy task. ... The inescapable conclusion appears to be that legislative intervention to fill the hiatus just mentioned and to reconcile the opposing philosophies that underlie the common-law rules and the provisions of the new divorce legislation is called for.

Twee teenstrydige filosofieë blyk die onderliggende verskil in onderhoudstoekenning te onderlê. Die skuldbeginsel blyk ingevolge die gemenereg, die onderhoudsaanspraak te beëindig indien applikant, die gesamentlike huishouding onregmatig beëindig het, terwyl die skuldlose egskeidingsreg, wat die Wet op Egskeiding 70 van 1979 voorsien, die onderhoudsaanspraak lewend (kan) hou. Die wetgewer het nog nie die leemte aangevul nie.

Daar bestaan egter regspraak wat 'n antwoord mag bied en vervolgens bespreek word. In Nilsson $v$ Nilsson (1984 2 SA 294 (K)) doen die applikante aansoek vir onderhoud pendente lite asook vir 'n bydrae tot koste vir die hangende huweliksgeding (295D). Die applikante en die respondent is beide bejaard. Sy is tydens die aansoek 78 en hy 85 jaar oud (295D). Hulle was vir ongeveer agtien maande getroud (295D), toe die applikante die gemeenskaplike huishouding en gesinswoning verlaat het (295D). Sy beweer dat die respondent die oorsaak is waarom sy die huishouding verlaat het aangesien hy haar beveel het om die huishouding te ontruim $(295 \mathrm{H})$. Die respondent is weer van mening dat die applikante die oorsaak vir die huweliksverbrokkeling is (296C) en dat sy hom verlaat het $(296 \mathrm{H})$. Regter Van Den Heever is van mening dat dit onbillik sou wees om aan applikante regshulp pendente lite te verleen sonder om op die meriete van die huweliksgeskil te let (295D). Hoe moet 'n aansoek soos hierdie beslis word sonder om onbillik te wees? Die antwoord in die woorde van regter Van Den Heever is dat "... law and fairness should if possible run hand-in-hand" (295C-D). Dit word bereik deur artikel 7(2) van die Wet op Egskeiding 70 van 1979 ook op aansoeke vir onderhoud pendente lite van toepassing te maak (297B \& 297E-F). Dit stem, sonder om te vermeld, ooreen met die siening van Sinclair, hierbo genoem. Artikel 7(2) bepaal dat die gedrag van die partye vir sover dit op die verbrokkeling van die huwelik betrekking het as een van die genoemde faktore in ag geneem mag word. Die hof vermeld dat die skuldige gedrag van 'n party veral in ag geneem sal word, indien die huwelik van kort duur was en die beëindiging van die huwelik nie tot verlies lei nie, soos byvoorbeeld verlies aan vorige onderhoud, ander 
huweliksverwagtinge of werk weens bedanking ensovoorts (297H-298A; sien Grasso v Grasso 19871 SA 48 (K) 53-54 waar die hof vermeld dat "[w]here, however, the misconduct of one of the parties is gross, fault not unnaturally assumes a greater relevance"). Die hof wys die aansoek vir onderhoud pendente lite van R600 per maand af op sterkte van die feit dat die huwelik van korte duur was en sy sedert sy die huishouding verlaat het haarself kon onderhou al was dit ook met die hulp van haar kinders (298A-C). Die hof is met ander woorde van oordeel dat sy in die hoofgeding nie suksesvol sal wees nie. Gedingkoste word wel toegeken aangesien respondent gewillig is om dit aan te bied (298D). Die belang van hierdie saak vir onderhoud pendente lite is dat die gemeenregtelike beëindiging van onderhoud deur skuldige gedrag nie absoluut toepassing vind nie, maar dat die faktore vir onderhoudtoekenning in 'n egskeidingsgeding wat hoofsaaklik met skuld weggedoen het, ook toepasbaar is by aansoeke vir onderhoud pendente lite.

Regter Mullins in Carstens v Carstens (1985 2 SA 351 (SOK)) is ook van oordeel dat die faktore vermeld in artikel 7(2) van die Wet op Egskeiding 70 van 1979 toepassing moet vind by onderhoud pendente lite (354C-D). Applikante en respondent het struwelinge met verloop van tyd gedurende hul huwelik gehad. Die laaste was toe applikante, die huishouding verlaat het en by haar minnaar ingetrek het. Hulle het ook sedertdien ' $n$ kind wat dit vir applikante moeilik maak om met haar werk voort te gaan. Nou eis sy onder andere onderhoud pendente lite. Die onderhoud pendente lite word nie toegeken nie, en die hof bied twee motiverings hiervoor aan. Een, die hof is van oordeel dat dit teen die openbare beleid is dat ' $n$ vrou, 'n aanspraak op onderhoud pendente lite teen haar man het, terwyl sy skandalig en voorbedagt as man en vrou met 'n ander man saamleef (353E-F; sien vir dieselfde standpunt Dodo $v$ Dodo 19901 SA 77 (W) 89F-G). Twee, die hof verwys (353H-I) ook na die mening van Hahlo (The South African Law of Husband and Wife (1975) 454) waar hy van oordeel is "... it is contrary to justice and equity that she should be able to collect support for the same period from her exhusband as well as from her 'putative' second 'husband'". Die hof beslis dan (353I): "I see no reason why a claim for maintenance pendente lite should not depend on similar principles of justice and equity". Daar is myns insiens geen substantiewe verskil tussen hierdie twee motiverings nie. Dit is dieselfde motivering of rede met verskillende woordgebruik. Die hof is van oordeel dat hierdie bevinding nie op 'n toepassing van die skuldkonsep neerkom nie (353I) en verwys dan na Singh v Singh (1983 1 SA 781 (K) 787). In laasgenoemde saak bevind die hof dat skuld slegs 'n rol speel indien dit as grof beskryf kan word (sien vir dieselfde standpunt Kroon v Kroon 19864 SA 616 (OK) 617H-I; Beaumont v Beaumont 19871 SA 967 (A) 994D-H; Kritzinger $v$ Kritzinger 19891 SA 67 (A) 80C-E; Dodo $v$ Dodo 89D-F, 92D-E; sien Barnard 'Enkele opmerkings oor die voorgestelde nuwe Suid-Afrikaanse egskeidingsreg' 1978 THRHR 263 277; Barnard 'Nog 'n stap nader aan 'n nuwe egskeidingsreg' 1979 De Rebus 11 14; Nathan 'Divorce Act 1979: "Fault" as a ground and "fault" as a factor, distinguished: Kennneth Daniels in 1979 DR 513' 
1979 De Rebus 675; Joubert 'Onderhoud na egskeiding’ 1980 De Jure 80 91; Sonnekus 'Onderhoud na egskeiding' 1988 TSAR 440 442-443 is van mening dat die strafgrondslag vir onderhoudsonthouding uitgedien is). Die onderhoud word in Carstens geweier omdat die beginsels van geregtigheid en billikheid by die toekenning, 'n afkeur het waar 'n vrou deur twee mans op dieselfde tyd onderhou word.

Die hof in Dodo $v$ Dodo word gevra om 'n bestaande onderhoudsbevel pendente lite te verhoog en om ' $n$ bedrag vir gedingkoste bykomstig tot 'n vroeëre bedrag te beveel. Sedert applikante, die huishouding verlaat het, het sy ook haar werk verloor en kan geen ander vind nie en vra sy 'n verhoging vir onderhoud pendente lite (80D-E). Respondent staan egter 'n bevel ter verhoging van die onderhoud pendente lite teen onder andere op grond dat applikante haar aanspraak op onderhoud verbeur het weens haar gedrag met ander mans (80G, 87F). As gesag vir die verbeuring van die eis vir onderhoud word daar op onder andere Chamani en Carstens gesteun (88C). Die hof in Dodo onderskei die Chamani-beslissing. As rede word onder andere aangegee dat in Chamani die gemenereg met betrekking tot die voorsiening van onderhoud toepgepas is (88G). Dit het beteken dat die skuldige sy aanspraak op onderhoud verbeur het (sien Chamani par 32 hironder). Hier word die gemeneregbeginsel met betrekking tot die verlies aan onderhoud nie toegepas nie, maar artikel 7(2) van die Wet op Egskeiding 70 van 1979 (88G-H) en dit bemagtg die hof om ook ander faktore as die gedrag van die partye in ag te neem $(88 \mathrm{H})$. Die hof wys daarop dat Carstens die onderhoud pendente lite afwys omdat dit teen die openbare beleid sou wees om dit toe te staan $(88 \mathrm{H}-\mathrm{I})$ en dan sê die hof:

It would appear from the Carstens' case supra that, in refusing an order for maintenance pendente lite, the learned Judge considered that the living together as man and wife, coupled with that man furnishing her with some support, is conclusive or so overriding as to render irrelevant the other factors mentioned in s $7(2)$

Hierdie woorde gee, ten spyte van die hof in Carstens se uitdruklike woorde dat die afwys van die bevel nie betrekking het op die gedrag of skuld van die applikante nie (353I), te kenne dat die buite-egtelike gedrag as oorheersende negatiewe faktor, die aansoek gekelder het. Alvorens die hof in Dodo sy bevinding maak, wys die hof (89B-F) op Hahlo (supra (1985) 371); Swart v Swart (1980 4 SA 364 (O) 368C-D); en Singh, wat almal met betrekking tot onderhoud ingevolge artikel 7(2) van die Wet op Egskeiding 70 van 1979 aantoon dat “... misconduct may be merely one of many features in which both parties contributed to the breakdown of the marriage, in which event a fair sum may be allowed as maintenance" (Dodo supra 89F) Die hof staan die aansoek vir die wysiging van die onderhoudsbevel toe (101G-I), omdat daar gronde vir wysiging aanwesig is en geen stawende bewys vir die onregmatige gedrag voorgelê is nie (90F-G, 91 A-B, 91G). Die hof gaan egter verder en sê dat artikel 7(2) aan die hof 'n wye diskresie gee wat inhou dat, desnieteenstaande applikante die huishouding verlaat en met 'n derde 
saamwoon, ander faktore wat die erns van die huwelikswangedrag van applikante mag neutraliseer ook in ag geneem mag word (92D-E).

Applikante in SP v HP (2009 5 SA $223(\mathrm{O})$ ) het die huishouding verlaat en doen aansoek om onderhoud pendente lite. Sy baseer haar aansoek op die feit dat sy werkloos is en dat vriende by wie sy woon haar onderhou, waarop sy nie meer kan of wil aandring nie (par 3). Respondent staan die aansoek teen $(224 \mathrm{H}-\mathrm{J})$. Hy voer aan dat applikant die huishouding verlaat het en by haar minnaar ingetrek het en sodoende haar onderhoudsaanspraak verbeur het (parr $5 \& 6$ ). Hierdie bewering word bevestig deur 'n verslag van 'n maatskaplike werker vir die kinderhof wat beveel het dat die twee minderjarige kinders van die partye in die sorg van respondent se broer geplaas word (parr $6 \& 7$ ). Regter-president Musi wys die aansoek om onderhoud pendente lite van die hand. As motivering vir hierdie beslissing word Carstens as gesag gebruik. Regter-president Musi vermeld dat die aansoek in Carstens afgewys is, omdat die hof van oordeel is dat dit teen die beginsels van geregtigheid en billikheid is dat 'n vrou, gelyktydig deur twee mans onderhou word (226C; sien hierbo). Hierdie beswaar teen die toekenning van onderhoud is volgens regterpresident Musi “... not so much about the moral turpitude attaching to the illicit cohabitation, but more about the notion of a woman being supported by two men at the same time" (226C-D; sien ook hierbo waar regter Mullins in Carstens supra 353I sê: "It is not a question of applying the 'guilt' concept to such an application"). Die toekenning word afgewys omdat dit, anders gestel, teen die openbare beleid of beginsels van geregtigheid en billikheid is dat 'n vrou deur twee mans onderhou word.

Die hof in SH $v$ EH (2011 5 SA 496 (OKP)) word genader om 'n onderhoudsbevel ingevolge artikel 7(2) van die Wet op Egskeiding 70 van 1979. Die beslissing is egter vir onderhoud pendente lite ook van belang. Daar is eenstemmigheid dat die huwelik tussen die eiseres en verweerder onherstelbaar verbrokkel het (par 2). Die feite van die saak word ook kortliks weergegee. Die partye is buite gemeenskap van goed getroud. Verweerder verlaat eiseres en die gemeenskaplike huishouding en trek by ' $n$ vriendin in. Ses maande daarna trek die verweerder by 'n ander man in. Hierdie verhouding is tans tien jaar aan die gang (par 6). Eiseres knoop nadat verweerder die huishouding verlaat het 'n verhouding met 'n gesinsvriend aan by wie sy ook tans bly en 'n intieme verhouding mee het (par 7). Die partye bereik 'n skikkingsooreenkoms in Julie 2003 waarin die verweerder onderneem om aan eiseres R3 000.00 onderhoud per maand te betaal. 'n Dag voordat die egskeiding gefinaliseer sou word, word die boedel van verweerder gesekwestreer en al eiseres se bates word ook op beslag gelê (par 9). Haar bates word eers in 2008 aan haar oorgedra (par 9). Intussen het sy niks om van te leef nie en word sy en haar minderjarige seun deur haar vriend en minnaar onderhou (par 11). In 2006 het verweerder ook die eiseresse aanspraak op sy mediese skema laat stop en in 2009 is die eiseres met kanker van haar onderkaak gediagnoseer en behandel wat haar ongeveer R150 000.00 gekos het (parr 12 \& 14). In April 2010 bring eisres in aansoek vir onderhoud pendente lite wat geweier is "... on the basis, inter alia, that it is unlikely 
that the plaintiff will succeed with a claim for maintenance in the court hearing the action" (498H). Met betrekking tot die eis vir onderhoud ingevolge artikel 7(2) van die Wet op Egskeiding 70 van 1979 voer verweerder twee verweersgronde aan waarvan die belangrike vir die saak onder bespreking is dat dit teen die openbare beleid is om onderhoud toe te ken aan 'n vrou wat deur twee mans onderhou word (vgl par 4). In antwoord hierop sê regter Schoeman (500B-C): "Through a long line of cases dealing exclusively with maintenance pendente lite, it has become customary not to award maintenance to a spouse who is living in a permanent relationship with another".

As gesag vir hierdie stelling verwys die hof na drie sake naamlik Carstens (500G); SP v HP (501A); en Qonqo v Qonqo (2010 (FSHC) 107; op $501 \mathrm{~B}$ van $S H \mathcal{V} E H$ ). Carstens en $S P \mathcal{v} H P$ is direk toepasbaar (sien ook die bespreking hierbo). In Qonqo, word die aansoek nie afgewys nie en die rede, volgens $S H v E H(501 \mathrm{C})$, is omdat daar geen bewys is dat applikante deur haar minnaar onderhou is nie. Aanvullend tot bogenoemde gesag met betrekking tot die toekenning van onderhoud pendente lite vermeld die hof in SH $v E H$ (par 32):

Marriage entails that the parties establish and 'maintain an intimate relationship for the rest of their lives which they acknowledge obliges them to support one another, to live together and to be faithful to one another'. [Dawood $v$ Minister of Home Affairs; Shalabi v Minister of Home Affairs; Thomas

$v$ Minister of Home Affairs 2000 (3) SA 936 (CC) par 30].

Hierdie woorde regverdig die gevolgtrekking dat onderhoud pendente lite onder omstandighede soos in SH $v E H$ nie toegeken sou word nie, indien dit vir beslissing gedien het (vir die bespreking van die onderhoudseis ig a 7(2) van die Wet op Egskeiding 70 van 1979, sien par 4 hieronder). Dit is jammer dat SH $v E H$ nie Dodo as gesag aanhaal dat artikel 7(2) van die Wet op Egskeiding 70 van 1979 'n wye diskresie ook by die vraag na onderhoud pendente lite verleen nie (sien die bespreking van Dodo hierbo). Daar is by my geen twyfel dat onderhoud pendente lite aan die applikante (eiseres) toegestaan sou gewees het, indien Dodo toegepas is.

Op appèl in EH $v$ SH lewer appèlregter Leach die volgende kommentaar (167E-H):

Relying on judgments such as Dodo $v$ Dodo ...; Carstens $v$ Carstens ...; and SP $v H P \ldots$, it was argued, both in the high court and in appellant's heads of argument, that it would be against public policy for a woman to be supported by two men at the same time. While there are no doubt members of society who would endorse that view, it rather speaks of values from times past and I do not think in the modern, more liberal (...) age in which we live, public policy demands that a person who cohabits with another should for that reason alone be barred from claiming maintenance from his or her spouse. Each case must be determined by its own facts, and counsel for the appellant (...) did not seek to persuade us to accept that the mere fact that the respondent was living with Mr Smith operated as an automatic bar to her recovering maintenance from the appellant. Instead he argued that the 
respondent had failed to prove that she was entitled to a maintenance order in her favour.

Hierdie dictum van die Hoogste Hof van Appèl stel dit, nieteenstaande dit 'n obiter dictum met betrekking tot onderhoud pendente lite is, sonder twyfel duidelik dat dit nie noodwendig teen die openbare beleid is nie om onderhoud pendente lite toe te ken aan 'n gade wat die huishouding verlaat het en in 'n buite-egtelike verhouding met 'n minnaar betrokke is. Die standpunt van Sinclair word, myns insiens, hier sonder uitdruklike vermelding deur die Hoogste Hof van Appèl aanvaar en ondersteun.

Ek sluit hierdie paragraaf af en doen dit by wyse van 'n opsomming. Gemeenregtelik is onderhoud pendente lite verbeur indien die applikant, die skuldige party was en die gesamentlike huishouding beëindig het. (Chamani $v$ Chamani supra). In Carstens word die onderhoud ook geweier uit hoofde van die feit dat dit teen die beginsels van geregtigheid en billikheid is dat ' $n$ vrou deur twee mans op dieselfde tyd onderhou word (sien ook SP V HP; SH $v$ EH hierbo bespreek). Sinclair (supra 97-98) kritiseer die gemeenregtelike skuldbeginsel en stel voor dat die wetgewer ingryp en onderhoud pendente lite op dieselfde basis as onderhoud ingevolge artikel 7(2) toeken. Laasgenoemde standpunt word vir die eerste keer sonder vermelding in Nilsson toegepas (sien ook Dodo; EH v $\mathrm{SH}$ hierbo bespreek). Die mees resente gesag ondersteun die gedagtegang dat die faktore in artikel 7(2) van die Wet op Egskeiding, 70 van 1979, die toekenning pendente lite ook moet beheer en onderlê.

\section{Bydrae tot die Koste van 'n Hangende Huweliksgeding Ingevolge Reël 43(1) van die Eenvormige Hofreëls}

'n Bydrae tot die koste van 'n hangende huweliksgeding word ingevolge Reël 43(1) van die Eenvormige Hofreëls gemagtig (Spiro 'Contributions towards costs in matrimonial causes' 1948 SALJ 421 is van mening dat omdat bydraes ook geëis kan word voordat die huweliksgeding ingestel is, 'n beter benaming bydrae stante matrimonio is).

Indien die partye binne gemeenskap van goed getroud is, het beide gades gelyke bevoegdhede met betrekking tot onder andere die beskikking oor die bates van die gemeenskaplike boedel en die bestuur van die gemeenskaplike boedel (A 14 van die Wet op Huweliksgoedere, 88 van 1984). Desnieteenstaande die feit dat artikel 17(1) van die Wet op Huweliksgoedere 88 van 1984, bepaal dat litigasie deur 'n gade teenoor derdes nie sonder die skriftelike toestemming van die ander gade mag geskied nie, is daar geen verbod in die Wet wat huwelikslitigasie tussen gades verbied nie. Hahlo vermeld in hierdie verband die volgende (supra (1985) 428):

Seeing that both spouses have equal powers of disposition, it is, at first blush, difficult to perceive why either of them should ever require a contribution towards costs from the other. However, in fact or in law, one spouse may hold the purse strings. ... In this case, she will be entitled to a contribution towards 
her costs, provided, of course, she can satisfy the court that she has a reasonable prospect of success.

In Carstens word die aansoek vir onderhoud pendente lite afgekeur (sien hierbo par 3 1), maar die aansoek vir tussentydse gedingkoste word egter toegestaan (354F). Die hof is van mening dat "[h]er application for a contribution is in a somewhat different position" (354D). Waarom is die hof van hierdie mening? Die hof verwoord dié mening só (354E-F):

However, I am prepared to accept in applicant's favour that she may have some patrimonial claim in respect of the assets of the joint estate. The parties were married in community of property and there is a house in the joint estate with a net value of about R60 000. I do not feel I should deprive applicant of the opportunity to seek to establish some claim to a share thereof (eie beklemtoning).

Hierdie motivering stem in wese ooreen met die mening van Hahlo hierbo. Die gade getroud binne gemeenskap van goed is geregtig op koste hangende die huweliksgeding omdat die applikant(e) 'n aandeel in die gemeenskaplike boedel het en redelike kans op sukses in die vermoënsregtelike eis in die egskeidingsgeding het. Hy wil haar nie haar eis met betrekking tot ' $n$ aandeel in die gemeenskaplike boedel ontneem nie, desnieteenstaande haar aansoek vir onderhoud pendente lite onsuksesvol is.

'n Kostebydrae word as deel van die onderhoudsplig beskou waar die partye buite gemeenskap van goed getroud is (sien oa Lyons $v$ Lyons 1923 (TPD) 345 346; Boezaart \& Potgieter $v$ Wenke 1931 (TPD) 70 83; Butterworth $v$ Butterworth 1943 (WLD) 127 129; Reid v Reid 770; Zaduck $\checkmark$ Zaduck supra 80C-D; Chamani supra 806D; Dodo v Dodo supra 96F; AM $\checkmark$ RM supra 227H; Spiro supra 420; Hahlo supra (1985) 428; sien egter Davis $v$ Davis supra 114, waar die hof aantoon dat daar 'n belangrike verskil tussen onderhoud en tussentydse koste bestaan en dit skep prima facie die indruk dat tussentydse gedingkoste nie deel van die onderhoudsplig is nie. Die eerste indruk word egter later duidelik gestel dat hoewel die logiese basis vir onderhoud en gedingkoste dieselfde is, die toekenning van die een van die ander mag verskil; sien ook Reid $v$ Reid supra 770). Die aanspraak op gedingkoste word ook verbeur, indien 'n gade getroud buite gemeenskap van goed sy/haar reg op onderhoud verbeur (sien Chamani supra 806H-807A, 808G; Dodo supra 97A). Die geldigheid van hierdie standpunt word vervolgens ondersoek.

Die hof in Carstens verwys (354F) na Chamani waar aanvaar is dat die partye buite gemeenskap van goed getroud was (Chamani supra 805D) en die aansoek om tussentydse gedingkoste afgekeur is omdat applikante haar aanspraak op onderhoud verbeur het (Carstens supra 354F-G). Hierop antwoord Carstens (354G): "This case was decided before the Divorce Act 70 of 197 came into operation. In view of the provision of that Act relating to property rights on divorce, it does not seem to me that the views expressed in Chamani's case necessarily still apply". 
Hierdie stelling regverdig die gevolgtrekking dat 'n aansoek vir tussentydse gedingkoste nie outomaties verbeur word nie, as onderhoud pendente lite verbeur word nie. Onderhoud pendente lite mag verbeur word, omdat daar geen redelike vooruitsig op sukses daarvoor in die hoofgeding bestaan nie, desnieteenstaande die onderhoud nie outomaties verbeur word weens die onregmatige verlating van die gemeenskaplike huishouding nie (dit is presies wat in Chamani en Carstens gebeur het, sien hierbo par 3 1). Wanneer dit kom by tussentydse gedingkoste verander die prentjie, indien die hoofgeding in plaas van of addisioneel tot onderhoud na egskeiding, ook 'n vermoënsregtelike eis bevat. Die fokus is nie alleen op onderhoud nie, maar bevat ook 'n aanspraak op bates. Die bepaling waarna in die Wet op Egskeiding 70 van 1979 in die aanhaling verwys word, is waarskynlik artikel 9 wat verbeuring van vermoënsregtelike voordele beheer. Die hof sou myns insiens ook 'n bevel vir tussentydse gedingkoste toegestaan het waar die eis in die hoofgeding, 'n eis met betrekking tot ouerlike verantwoordelikhede is (sien ook Heaton South African Family Law (2010) 189), desnieteenstaande applikante die huishouding onregmatig verlaat het en die alleenoorsaak vir die huweliksverbrokkeling was. Dieselfde beslissing sou ook gehandhaaf word waar die applikante, 'n aansoek om tussentydse gedingkoste bring vir 'n hoofeis by egskeiding ingevolge die aanwasbedelling of herverdeling van bates ingevolge artikel 7(3) van die Wet op Egskeiding 70 van 1979, en die eis vir onderhoud pendente lite nie suksesvol is nie.

Hierdie siening word myns insiens in SP $v$ HP ondersteun wanneer regter-president Musi daarop wys (par 11) dat desnieteenstaande applikante se aansoek in Carstens vir onderhoud pendente lite afgewys is, sy wel met tussentydse gedingkoste geslaag het. Die rede hiervoor verwoord hy só (226D-F):

The rationale for this was that the parties were married in community of property and as such the applicant had a share in the assets of the joint estate. It was held that she was entitled to claim such share through the divorce action and for that reason she was entitled to a contribution towards the costs to enable her to pursue her claim. In casu the parties are married out of community of property and there is no indication on the papers that she is making any claim against the estate of the respondent (eie beklemtoning).

Die aansoek vir tussentydse gedingkoste word gevolglik in SP v HP van die hand gewys (par 12) omdat applikante geen hoofeis met betrekking tot vermoënsregte maak nie.

Die gesag hierbo vermeld, toon myns insiens aan dat dit irrelevant is of die partye binne of buite gemeenskap van goed getroud is. Die sukses van die aansoek vir tussentydse gedingkoste berus op die redelike vooruitsig van sukses op die regshulp in die egskeidingsgeding. Dit regverdig verder dat die grondslag van die aansoek vir tussentydse gedingkoste, wat as deel van die onderhoudsaanspraak gesien is waar die partye buite gemeenskap van goed getroud is (par 32 hierbo en gesag 
daar vermeld), verander is en dat dit op die beskerming van die regshulp in die egskeidingsgeding berus.

\section{Onderhoud Ingevolge Artikel 7(2) van die Wet op Egskeiding 70 van 1979}

Die hof in $S H \mathcal{V} E H$ staan vir die eerste keer in ons regspraak, onderhoud aan die eiseres toe, desnieteenstaande die feit dat die eiseres in 'n buiteegtelike verhouding met haar minnaar saamleef (parr 49 \& 51; vir 'n opsomming van die feite sien par 31 hierbo). Die hof kom tot hierdie beslissing deur op drie aspekte te wys.

Eerstens, verwys die hof na die doelstelling van artikel 7(2) en vermeld dat artikel 7(2) se bewoording nie voorsiening maak dat onderhoud verval wanneer die ontvanger in 'n verhouding verwant aan 'n huwelik met iemand saamleef nie. Dit sal plaasvind wanneer die onderhoudsooreenkoms ingevolge artikel 7(1) daarvoor voorsiening maak (par 31).

Tweedens, skep saambly geen onderhoudsplig ex lege nie en die hof verwys (par [33]) dan na Volks $v$ Robinson (2005 5 BCLR 446 (KH) parr $55 \& 56)$. Dit bring mee (par 34):

From this decision it is clear that the plaintiff has no right to maintenance from S now or in the future unless they get married.... The plaintiff is adamant that she cannot marry $\mathrm{S}$ due to her age and health. It is also clear from her evidence that she cannot earn an income for the same reasons. ... The reasons for plaintiff's decision not to marry $\mathrm{S}$ are reasonable under the circumstances of the case.

Derdens, verwys die hof na die faktore vermeld in artikel 7(2) en sê dat die faktore nie eksklusief of uitputtend is nie en dat die hof enige ander faktor wat na oordeel van die hof in aanmerking geneem behoort te word, in ag mag neem (par 36). Die hof opper dan die vraag (503I): "Can it be said that the fact the the plaintiff is living with $\mathrm{S}$ is determinate of the issue?" Die hof beantwoord die vraag in die volgende woorde (503I-504D):

When the plaintiff and her son were in dire straits due to the sequestration of the defendant's estate and the subsequent attachment of the plaintiff's property, it was $\mathrm{S}$ who supported plaintiff and $\mathrm{M}$ when the defendant failed to do so. It is immaterial whether the defendant was unable to support the plaintiff and their son, or whether he was merely unwilling to do so.

[41] Other legislation also makes it clear that the legislature envisaged that a man can be supported by two women. In terms of the provisions of $s$ 8(4) of the Recognition of Customary Marriages Act 120 of 1998, a court dissolving a customary marriage has the powers contemplated in ss 7, 8, 9 and 10 of the Act. This has the effect that with polygamous customary marriages a husband will have the right to be supported by more than one wife, post-divorce, if circumstances demand it. Although it might have been a concept that was unacceptable in a previous dispensation, the concept is not unacceptable today. 
[42] I am of the opinion that in the circumstances of this case it cannot be said that it is against public policy that the defendant should be liable to pay maintenance to the plaintiff; there is no legislative prohibition and I find that there is no general public policy to that effect or moral prohibition.

Die hof maak gevolglik 'n onderhoudsbevel van R2000.00 per maand ten gunste van eiseres (par 48). Eiseres het R5000.00 per maand geëis en selfs dit merk die hof op, sou nie ten volle in haar onderhoudsbehoeftes voorsien nie (504H-I). Omdat die verweerder se boedel onder sekwestrasie is, is hy ook nie in 'n posisie om, volgens die hof, haar meer as die toegekende bedrag te betaal nie (parr $44 \& 48$ ). Hoe die tekort aan haar lewensonderhoud aangevul word, word nie vermeld nie, maar dit is nie vergesog om te dink en te meld dat dit deur S aangevul sal word nie, alhoewel hy nie daartoe verplig is nie. Die gevolgtrekking kan gehandhaaf word dat dit nie teen die openbare beleid is nie dat 'n geskeide gade beveel mag word om onderhoud te betaal indien omstandighede dit regverdig, desnieteenstaande die feit dat die ander gade in 'n buite-egtelike verhouding betrokke is en ook deur die minnaar onderhou word.

Die verweerder appelleer egter teen die beslissing en die hof in $E H v$ SH staan die appèl toe (parr $15 \& 17$ ). Die rede waarom die appèl suksesvol is, word gemaak op 'n basiese beginsel wat op onderhoudstoekenning van toepassing is, naamlik die eiseres (of dan die respondent in die appèl) het nie 'n behoefte aan onderhoud bewys nie (parr $13 \& 14$ ). Die Hoogste Hof van Appèl het egter nie bevind dat die beginsel soos verwoord in die hof a quo, sonder regsbegronding is nie. Inteendeel, daar is stilswyende goedkeuring dat onderhoud ingevolge artikel 7(2) van die Wet op Egskeiding 70 van 1979 toelaatbaar is, wanneer die eiser in 'n buite-egtelike verhouding met 'n minnaar saamleef en omstandighede die onderhoudstoekenning regverdig (sien die bespreking hierbo par 3 1).

\section{Slot}

(a) Die beleid met betrekking tot onderhoudstoekenning pendente lite het verander. Die gemeenregtelike skuldbeginsel dat die applikant(e) onderhoud pendente lite weens onregmatige gedrag verbeur, word deur die meerderheid van resente gesag verwerp. Die sukses van die aansoek berus op die redelike vooruitsig van sukses in die hoofgeding (sien par 3 1 hierbo).

(b) Die standpunt dat die onderhoudsaanspraak, die grondslag vir 'n aansoek vir tussentydse gedingkoste is waar die partye buite gemeenskap van goed getroud is (par 32 hierbo en gesag daar vermeld), word ook verander. Die sukses van 'n aansoek vir tussentydse gedingkoste berus op die redelike vooruitsig op sukses van die hoofgeding.

(c) Paragrawe (a) en (b) plaas dus die sukses van beide aansoeke op dieselfde beleid en grondslag. 
(d) SH $v E H$ bevind vir die eerste keer in ons regspraak dat onderhoud ingevolge artikel 7(2) van die Wet op Egskeiding 70 van 1979 toelaatbaar is, ook as 'n gade in 'n buite-egtelike verhouding met 'n minnaar saamleef. Die hof kom tot hierdie beslissing op grond van onder andere artikel 7(2) wat die hof magtig om enige faktor te gebruik wat na oordeel van die hof in aanmerking geneem mag word (sien par 4 hierbo).

LN VAN SCHALKWYK

Universiteit van Pretoria 